\title{
МЕТОДИЧКИ ПРИСТУП ДЕЛУ ДОБРИЦЕ ЋОСИЋА У ОСНОВНОЈ ШКОЛИ
}

\begin{abstract}
Аутор полази од програмских прилика и методичке праксе у обради уметничких текстова Добрице Ћосића у основној школи, и са тих позиција, на пробраним примерима - настоји понудити неке нове методолошке осврте на тематско-мотивску грађу Ћосићеве прозе, условно речено, за децу - а заправо примерену језичким и сазнајним могућностима ученика основношколског узраста. Сходно овој идеји, аутор предлаже препознавање тематски разноврсних мотива са истицањем доминантних, а то су националне и породичне вредности, уопште узев - хумане.
\end{abstract}

Кључне речи: Добрица Ћосић, методика наставе, стилизација, нарација, дескрипција.

\section{1. Увод}

1. Програмом српског језика и књижевности за обраду у основној школи предвиђен је један текст Добрице Ћосића: уводно поглавље романа Деобе са насловом Ойкриће. Прегледали смо читанке у издању различитих издавача - Завода за уџбенике (Бајић, Мркаљ 2016), Клета (Несторовић, Грушановић 2016) и Логоса (Станковић Шошо 2016), - утврдили да је у свим издањима узет исти исечак текста из романа Деобе, те и да је у свим поменутим читанкама спроведена адекватна књижевно-теоријска и методолошко-методичка обрада одломка. Сви истраживачки задаци прилагођени су перцептивним могућностима ученика осмог разреда, теоријски су израсли из градива усвојеног у претходним разредима и на часовима књижевне историје и критике у осмом разреду, те и, најважније - прорачунати су на неговање естетских осећаја у ученика, стицање знања из области анализе текста уопште, посебно уметничког, али и, додуше индиректно, упознавање са тзв. поетском

\footnotetext{
*vasdejks@gmail.com
} 
стилистиком и тумачењем текста. Ова наша запажања иду у ред похвала састављачима програма и, посебно, састављачима читанки и других наставних практикума.

2. Овде ми, међутим, желимо указати и на неке друге могућности у увођењу дела Добрице Ћосића у основношколску наставну праксу. Стиче се утисак, шире узев, да се састављачи програма, а и уџбеничке литературе, руководе начелима која не стављају у средиште општу уметничку вредност књижевних дела и, наравно, пријемчивост текстова за основношколски узраст, већ уз овај потоњи рекло би се стоји начело модерности.

a) Старији писци предсоцијалистичког и поготову социјалистичког периода - сем часног изузетка који чини Бранко Ћопић - полако ступају у позадину уступајући место актуелнијим или можда тренутно, по овој или оној вануметничкој линији утицајнијим, нашим савременицима. Не бисмо се овом приликом упуштали у претпоставке око разлога за овакав поступак, него ћемо уместо тога размислити о теми нашега прилога, тј. о могућностима ширег обухвата Ћосићева дела основношколским програмима. При томе ми настојимо да ослободимо и сопствено размишљање извесних предрасуда кад је реч о овој тематици, пре свега идеолошких, које би можда биле од утицаја на одбир писаца и њихових дела за школску употребу.

б) Генерације данашњих професора не би требало да буду оптерећене - а рекло би се да у великој већини и нису - теретом Другог светског рата и његових последица на психу човека. Поготову се то односи на генерације ученика основне школе, рођене углавном после 2000. године. Уз ово оптерећење долази још једна заблуда текуће књижевне критике, која је од одлучујућег утицаја на школску праксу. То је опсесија тзв. модерношћу. Залажемо се, наиме - како је у старо време имао обичај говорити Богдан Поповић (2001) - за естетски критериј, како у оцени књижевних остварења тако исто и у њиховом третману у дидактичке сврхе.

в) Модерност, коју поменусмо, супротстављена застарелости као јединој квалификацији старије књижевности српске, не бисмо рекли да је до краја, чак не бисмо рекли да је уопште прихватљив критериј, поготову да је прихватљив и продуктиван као дидактичко руководство. Старија књижевност носилац је једног много достојанственијег и у суштини истинитијег атрибута од застарелости - то је оно што садржи појам 'класике', или ако ћемо се по сваку цену чувати патетике, онда бар појам 'националног наслеђа', поред интернационалног или, како неки кажу, светског литерарног корпуса.

3. Рекосмо: добро би било одложити устрану, поред поменуте корупције, и идеолошке критерије. И добро је што се то у неким случаје- 
вима чини, као што је поменути Бранко Ћопић, који сам својим делом далеко превазилази своју партизанску биографију и своја послератна опредељења. Није, хоћемо рећи, ствар само у његовом познатом политичком гесту јавног одбацивања неприхватљивог схватања и понашања већине тадашњих интелекуалаца. Тај гест сам по себи не би могао спасти његово дело од заборава да оно не заслужује пажњу данашњих генерација по својим уметничким квалитетима и људским порукама.

а) Ако одлучно одбацујемо својевремено ћутање о Јовану Дучићу и Милошу Црњанском, на пример, немамо разлога ћутњом претрпавати ни квалитет оних великих стваралаца који са данашњег гледишта изазивају контроверзе око понашања и политичког ангажмана у овом или оном периоду својега живота. Није потребно, наравно, прећуткивати било који позитивно утврђен податак ни из биографије Добрице Ћосића, уколико је тај податак релевантан за утврђивање истине о његовом животу.

б) Али књижевно дело не дугује своју егзистенцију, своје вредности и заслуге за националну културу - само и једино биографији и политичким схватањима писца. Рекосмо да је Ћопић својим делом далеко превазишао део своје биографије који би неки данашњи биографи ради били да их прецртају, еда би великог песника приказали само у једном, једностраном светлу, као што су неки њихови претходници прецртавали Црњанског, Дучића, па и Иву Андрића, и многе друге величине чије би одбацивање или прећуткивање значило смрт књижевноуметничкој величини српског народа.

4. Иста је ствар и са Добрицом Ћосићем. Зато се ми покушавамо удубити у Ћосићево стваралаштво без 'ратне секире', а искључиво с намером да пронађемо још који могућ текст у његовом делу који би заслуживао пажњу и напор програмера и методичара књижевности да се укључи евентуално у програм за обраду у основној школи.

\section{2. О неким методичким могућностима обраде Ћосићевих текстова у основној школи}

1. Прво Ћосићево дело које препоручујемо за наставу и на коме ћемо се најдуже задржати - јесу Корени (1954), првенствено због њиховог општенационалног и универзалног уметничког значаја ${ }^{1}$, али посебно због могућности коришћења тематске и језичке његове грађе за

1 „Они - по речима Б. Михајловића (1954: 11) - у својој тематској слојевитости значајно осветљавају сложену проблематику српског националног мита, митског мишљења људи XIX века, снаге и валоризације неких култова националне митологије, односно српске интелигенције према националној митологији као и процеса њене трансформације у конституисању грађанске културе". 
различите методичке потребе. У Коренима, наиме, проналазимо језичку грађу интересантну за различита истраживања у настави нормативне граматике, дијалектологије и лексикологије - као што су локализми и дијалектизми, те и однос футура и тзв. футуроида, стандардно оформљених реченица и ирегуларних граматичких форми исказног статуса и сл. Све су ове појаве анализибилне и са становишта нормативне и структурне стилистике, те и стилистике поетског текста (према: Лотман 1976; Симић 2000) - као, на пример, експресионизми, маркирани фразеологизми, народски изрази и форме, стилске фигуре и поступци итд.

1.1. Утицај косовско-ресавског дијалекта у Коренима - како је већ опажено (Јовановић 2000: 641-676; 2009: 163-176) - „не исказује се у целокупној структури језика, али је у неким категоријама несумњив: (а) у структури и интонацији исказа, (б) у лексици и (в) у честом изграђивању метафорике на основу говорног израза (дијалекта). Овај стилски поступак спроведен је делом свесно, интенционално, делом спонтано. Наравно, има примера где изграђује властити књижевни исказ и тежи што већој индивидуализацији: - то су искази који носе највећи печат изворног, регионалног".

a) Најпре, и конкретно говорећи, наставу граматике веома је сврсисходно повезати са наставом књижевности када се за пример локализама и дијалектизама узме грађа из Ћосићевих Корена. У том смислу могућно је уочити фонетске дијалектизме (исп. іуувно ум. іуммно), те обличко-творбене ( gа би живели ум. gа бисмо живели, живоиинка 'покр.

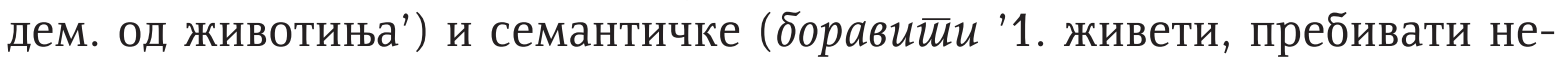
где... 2. проводити време...'), као и локалне фразеологизме (Душа се носи, іола као леска и сл.) $)^{2}$. Ови последњи - семантички и фразеолошки локализми - битно утичу на идиосинкратичност Ћосићева језика и добар су симптом лиризације приче и сликовитих исходишта пишчеве имагинације. Као најчешће средство микрокомпозицијског усликовљења пишчевих идеја - изрази и конструкције локалне ${ }^{3}$ провенијенције знак су и стилскоформацијског локализовања и колоризовања Ћосићева говора као романтичарско реалистичног или модернистичко реалистичког. Ученицима се на тај начин указује на чињеницу да је народна реч, схваћена и у ужем смислу као обнова лексике, али и у ширем као обнова и богаћење фразеологије, творбених средстава, синтаксе итд. - од велике важности за очување и проширење духа и функционалних моћи књижевног језика. А поред тога ученици могу уочити како су у Ћосића најчешћи творбени и семантички локализми - према истраживањима J.

${ }^{2}$ Грађу дајемо према: Јовановић 2009: 163-176; значења проверавамо у: РМС 1967-1976: s. v.

${ }^{3}$ УП. нпр. о дијалектизмима у реализму: Симић, Јовановић Симић 2017: 407-417. 
Јовановић (2000: 674-676), - те да мањи део грађе отпада на фонетске и семантичке, а сасвим незнатан број на локалне фразеологизме.

б) Друго, у језику Корена општи однос футура и форме са „да + презент" показује пишчеву тенденцију ка стандрадизацији израза, јер је трипут више употребљених облика футура у односу на футуроид - према налазима Р. Симића (2009: 51-55). Испоредимо само неке футуре:

Моје око неће йромашитии (Кор. 16); Одмах се видело да ће битии леп и крупан (Кор. 31); Ти и ја бићемо од данас пријатељи (Кор. 135); [...] он ће му њиву gати да ћути (Кор. 181) и сл.

Њих треба поставити према супстандардним облицима футуроида, као формама које су Ћосићевом идиому природније:

Тада ћу gа ти кажем шта треба да радиш (Кор. 15); Због тебе ће моја кућа ga остиане пуста (Кор. 35); [...] сви ће они на мене gа йруже прст (Кор. 107) итд.

Ово ученицима може бити интересантан податак у упознавању пишчеве стилизације грађе, посебно када се у обзир узме да дијалекатску базу књижевних ликова ${ }^{4}$ у Коренима чини косовско-ресавски говорни тип, у којем је футуроид не само нефакултативна него скоро једина употребна варијанта за изражавање будућег времена. Поред тога, упућивањем на одговарајуће примере ученицима се може скренути пажња да се футуроид често узима за значења која одражавају несигурност, жељу, предвиђање и слична модална значења. Испоредимо само два-три примера из шире грађе коју наводи Р. Симић (2009: 51-55):

Снагу ћу ја ga му gам (Кор. 16); А за што ће gа изуии тамо? (Исто, 33); Кад

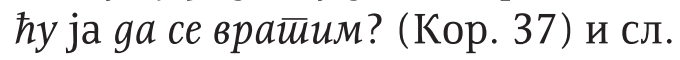

1.2. У настави је, даље, пожељно уочити, разуме се, на одговарајућем одломку или одломцима, - и специфичан приповедачки склоп у Коренима, који настаје прожимањем ${ }^{5}$ тока мисли и тока свести. На овај начин ученици се сусрећу са питањима синтаксе српског језика, с једне стране, и анализе уметничког текста и стилистике, с друге. Нпр.:

Некада. Он не долази кући као некада. Мајка је умрла. Шта може? Ено га гробље. Ту је она. Није јој отишао на гроб. Ништа она од тога нема. Никад више неће... не постоји за њега. Баба Ката. Велика бритва на дугој узици (Кор. 39).

${ }^{4}$ Разуме се да и на овом језичком моменту Ћосић проводи карактеризацију својих ликова, комбинујући га редовно са сложенијим сижејно-наративним поступцима (исп. Симић, Јовановић 2011: 319-334).

${ }^{5}$ Овај композицијски моменат је опазила Јелена Јовановић бавећи се исказним структурама у роману Корени (2000: 674-676). 
Сменом непредикативних и монопредикативних исказа, са изостављеним форичким везама, али са снажном тенденцијом изградње унутрашње форме сегментног итегратива - исказни се низ управо линеарним напредовањем композицијски деградира на различите вербатолошке облике. Структурно и садржински посматрано, они нису изградили свој статус текстеме, ни аутоидентитетски ни међуисказно. Они су, заправо, на нивоу тематских сигнала. Текстовни сегмент почиње иницијативом Некаga, а завршава се номиналним констативом Велика

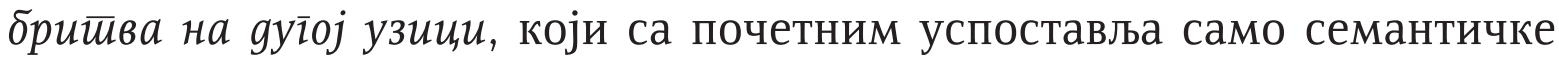
везе алузивне природе. Уланчавање исказа - могло би се са ученицима приметити - није прорачунато на постизање кумулативне информативности у комуникативном смислу, већ на интензификацију информације и продубљивање сугестије у поетском кодирању поруке.

a) Уз то, за анализу текста ваља приметити да се Ћосић служи дијалогом и унутрашњим дијалогом или монологом ${ }^{6}$, при чему је овај други вербализацијска и персонализацијска форма подсвести, што Ћосићу даје повода за његову дијалогизацију. Узећемо, чини се, најрепрезентнији и најчешће навођени сегмент за илустрацију ове међуисказне појаве:

Добро вече, Симка... снајка! Добро вече, снајо! (Нема смисла, загрцнула се од радости, ништа јој нисам донео)... Нисам могао да вам јавим, донео сам одлуку на брзину, морам одмах да се вратим... (Шта ја могу? Морам је разочарати). Па јесте и за Божић. Толико година нисам био код куће за Божић. Нисам те видео... Да, да, седам година! Париз, па одмах служба и државни чиновник... (Он! Жао ми, шта могу?) Добро вече, Ђорђе (Кор. 41).

Ваљало би са ученицима препознати дијалошко-монолошке сплетове, покушати разграничити ове говорне облике, бар персонално позицијски, и утврдити место синтаксе у њиховом разграничењу - идентификовати, то јест, уводницу и наводницу, па и трагати за било каквом правилношћу у смени реплика.

б) Поред тога, примећено је да Ћосић често гради безличне, пасивне и активне конструкције са рефлексивном речцом (Јовановић 2000: 674-676), па се погледом у грађу ученицима може на поетизованим исказима указати на синтаксичку, прагматичку, па и стилистичку разлику ових облика: док за радње саопштене активом постоји могућност њиховог вољног усмеравања, дотле пасив и рефлексив делују неопозиво, намећу се као стање које се мора прихватити:

Све остало је погубљено (Кор. 104); Коњи су упрегнути (Кор. 31); Санке су спремне (Кор. 31); Зна се! (Кор. 17); Да се чека (Кор. 200); Све се пла-

${ }^{6}$ Уп. о овим типовима говора и код: Ковачевић 2012: 13-38. 
ши царске силе (Кор. 90); Зар се мало причало по селу? (Кор. 19); Види се и у мраку (Кор. 44); Време је да се бадњак унесе (Кор. 43); Не сме да се погази (Кор. 37); То је добро: мање се жедни (Кор. 274); Јатаган мојега домаћина има да се чува у овој кући (Кор. 202); и сл.

в) Када се већ микроаналитички разматрају Корени, те се у стилизацији исказа открива њихова лингвистичка основа - корисно би било уз пасивне исказе издвојити и друге специјалне форме, на пример оне које као синтаксички дефектне своју комуникативну вредност остварују као тзв. глобални искази. Ево неких примера исказа-речца (везника):

Срамота је! - Ако! (Кор. 221); Она рађа. И цвет и трн. Ако (Кор. 221); Ако. Плаћам дупло (Кор. 181); Ако (Кор. 222); Ако, ако. Срце ми је веће од Ртња (Кор. 145); Ако. Спашћу се (Кор. 165); Па? - Ийак. - Па ийак (Кор. 66); и др.

Прво треба истаћи са синтаксичко-стилистичког становишта њихову високу контекстуализованост и комплетираност у наративном блоку, а онда, с тим у вези, код неких, као Ако - диктум-модусно померање, док код других, као Па ийак - комплеметарност и концесивност. Ученицима би се могла скренути пажња и на њихов статус у савременом језику, у коме је констативно-потврдно Ако типични маркер колоквијалне наративне дискурзије, а да су његови корени у усменој нарацији. Нешто слична ситуација је и са упитно-исказним Па?, и његовом унутарисказном или међуисказном варијантом $\bar{u} a$ uйaк. Често је у Ћосића читав низ узастопних исказа такав, те ови стварно непотпуни искази значајно доприносе вернијем приказивању психолошких стања личности.

г) Као посебне исказне форме налазимо и тзв. типичне исказе: дакле, негације и афирмације (Не/Да), као и општа питања и одговоре

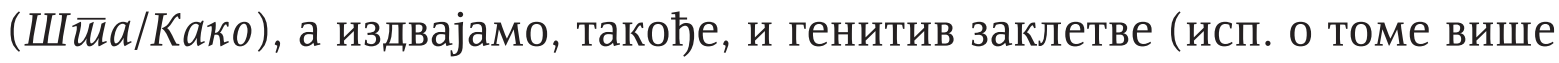
у: Јовановић 2000: 658):

Јок, руку ми мојих (Кор. 143); Никада се нисам слагао с њим, сина ми

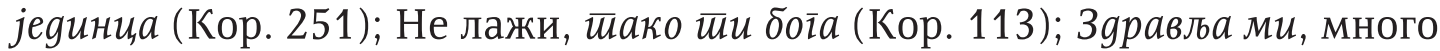
је лепша од оне о Тимочкој буни (Кор. 151); Нисам боїа ми, зgравља ми, среће ми (Кор. 184); Дешетеиа ми, никикво зло нећу да учиним (Кор. 198); Руку ми мојих, јер њих сам навек највише волео (Кор. 217), и сл.

1.3. И у свим горепоменутим аспектима ${ }^{7}$ посматрања језичке и наративне грађе у Коренима може се са ученицима препознавати њен стилски потенцијал, њена стилска вредност и стилска обележја. Но, могу се осмислити и посебни часови или делови часова на којима ће

${ }^{7}$ Исп. текстолошка истраживања: Јовановић Симић 2016: 229-242; Јовановић Симић 2017: 75-93. 
бити истраживан нпр. паралелизам исказа у Коренима. Као што смо у претходним примерима имали случај стилизације засноване на редуктивним и рестриктивним поступцима, те смо могли пратити како писац своје исказне структуре своди на релевантне делове исказа, скоро без изузетка, номиналне, - тако сада можемо са ученицима пратити супротан стилистички поступак: редундантност.

а) Она се остварује као посебта врста експанзивности, заснована на накнадном именовању, преименовању или доименовању ознаковљеног дела стварности. У том поступку Ћосић се води изоморфичним поступком - па се у резултату оваквог понављања јављају синтаксички паралелизми. Нпр.:

Стала је. Зар са Толом? Њеним наgничарем (Кор. 164); Јабуке је садио његов отац за Ђорђа и Вукашина. И јасенове око gворишйа (Кор. 188); и многи др.

Тамо где бисмо очекивали један исказ - Ћосић их парцелише у два. „Накнадним додавањем засебних синтаксичких и интонационих целина оправдава и њихово накнадно јављање у свести, али их враћа своме извору: реченици као контексту која се у њих распала - и утонула" (Јовановић 2000: 650-660). Стиче се утисак како ови искази изневеравају прозни језик: као да мисао не претходи речи те ни исказ није средство са утилитарним смислом (исп. Абот 2009). Приповедач их просто натурализује, ослобађајући их уобичајених правила, а опет водећи рачуна да неочекивани и онеобичајени комплекс оствари своју идејну конзистентност.

б) Репетитивност лексичких јединица чест је начин остваривања микротематске, тј. мотивске актуализације:

Веруј ми, у злу сви су зли (Кор. 11); Рука гужва браgу и бива све мокрија. Мокра је и браgа. Мокри су и дукати (Кор. 19); Ове јесени и ове зиме (Кор. 20); и други сл.

Овим путем остварују се снажне анафоричко-катафоричке везе подржане често пронималним супституентом номинала у антепозицији - у привидној линеарној прогресији, а заправо у кратком дистантном простору у коме се реализује наративна ретардација:

Лево! Лево! (Кор. 40); Јеgно мене коље. Само јеgно (Кор. 37); Добро вече, Симка... снајка!... Добро вече, снајо! (Кор. 37); Родио си газди слуіу.... Мени си родио слугу $y$. Теби Ђорђе Катићу ја нисам родио слуї... Неће бити твоје слуїе (Кор. 66); Моја соба... Вукашинова соба (Кор. 142); Ноћу је човека бранила од куиића. Погане животињке изгризоше јој руке, давила их је њима, па је све била нагрђена крвљу. Кучићи су јој и хлеб јели и воду локали (Кор. 260). 
Поновљени исказ, на пример (Лево!) Лево! - по мишљењу Јовановић (2000: 657) - „продужава трајање претходног као свог одјека, па се реализација његова остварује као линеаризација остварена опетовањем".

в) Иако са становишта синтаксичке повезаности и семантичке логичности у Коренима налазимо одступања која нарацију доводе до њене негације, тј. лиризације израза - управо у тим поступцима писац проналази огроман стилски потенцијал за вербатолошку реализацију описа и приповедања (уп. Шкловски 1966: 12-21; Јовановић Симић, Симић 2015). Нпр.: Ђорђе [...] gуі̄овима за іушу gржи неколико села. Уз то, акустичке слике најчешће су персонификоване, као у пр.: Мрак йушиюи у каиама, јечи и хукће у ирним іомилама, а поређења су из лексике и семантике говора сеоског света: Живим ирње оg манасииирскої йса. У Коренима налазимо и хиперболисане исказе: Преровски поп Величко за жену бu u cuњ море йреїазио, као и метонимијске: Шубаре и шещири йреg њим gо колена йagajy.

г) Препознавање песничких слика и фигуративног обликовања језичке грађе могуће је, даље, са ученицима спровести на примерима неких од бројних експресионизама - лексичких, синтаксичких и реченичних. Исп. неке случајеве:

Љуgu моїа лишћа ћутањем морају да се бране (Кор. 8); Каg месеи йойасе ноћ, до зоре луњам ливадама и стално се сагињем као да купим нешто (Кор. 10); Само у јесен шайућу каще йуне шљива (Кор. 11); Само су сийне ййице шарене. Гаврани су ирни. Ни орлови се не китее (Кор. 13); Најире йламен йробоgе мрак (Кор. 14); Мрак је као вода иеекао пред њим и њиме (Кор. 241); Отвара прозор и guше звезgе (Кор. 241); У полутами - жутњикав левак свеитлосии (Кор. 246); Ваљда јој се учинило да су Аћимове очи зрна ірожђа (Кор. 250); Устаде и стаде у сунчеве виле (Кор. 250); Овде му се сеgина избистирила, оирала у несаницама, очврсла у упорности (Кор. 250); Да би живели, ми се жилама калемимо (Кор. 259); Баіррем има шубару, изубаgан је јатиаїанима, а хоgа (Кор. 261); Неки су казивали да у глуво доба по утринама из земље излећу злайне йчеле (Кор. 261); Сањах расцветани баїрем шйо хоga (Кор. 262); Па ћу да загазим у живо, звонко месо реке (Кор. 265).

г1) Као што се може приметити, експресионизми настали поређењем, персонификацијом, метафором или анестезијом ма колико да су из живота и начина мишљења сеоског света, нимало нису репрезенти овог природног идиома. Они су чиста поетска сугестија.

г2) Једна од важнијих одлика Корена јесте и ритмичност исказа, а доминантна форма метричке самерљивости, а фолклорне провенијенције - јесте десетерачка. У том смислу ученицима би се могла издвојити 
сцена преровске битке у којој први десетерац изговара надничар Тола Дачић: - Да сељаци суgе сељацима (Кор. 75), и могло би им се, с тим у вези, указати на друкчију обојеност десетераца Аћима Катића, радикалског првака:

Боље, браћо, Турци да се врате (Кор. 115); Аћим Катић неће вас издати. Никада то није учинио (Кор. 127); Зар на вашу браћу и очеве? (Кор. 131).

Десетерачке варијације исказа послужиле су Ћосићу - могло би се закључити у интерпретацији, а на основу успоредбе - да стилски диференцира говор надничара од говора газде, јер су и њихови мотиви различити. Посматрајући недисциплиновану војску, Никола, на пример, огорчено запева: Леие иессме йеваће вам тајка, а Турии ће оиети као йшенииу ga їазе Србију (Кор. 134); да би одмах затим изразио дивљење према сељанки која је храбро у крв загазила: Ej ga сам йе некаg млађи срео. Овоме ваља прикључити и тринаест десетераца које поводом буне уз гусле пева Аћимов слуга Мијат (Кор. 150-151):

Сунце пишти, утрнутих зеница / „Помози нам горских смрека мајко! / Тором - вуци, време - наопако. / Реци како крв да људску смирим? / Да ли буну опет да распирим?” / Одговара Аћим крај ханџара: / „Бриши сузе, пламен испод стреје, / Букни, земљо, и Бог нек се згреје. / Гневом мртвих, живи мрште веђе, / Па насрни на то мртвојеђе". / И опет се са Катићког крова / Зора гласа из Црног Прерова [...].

Мијат, уплашен изненадним Николиним доласком, импровизује баналне конструкције - такође у десетерачком метру: - Па шйо ми се ирво не окажеш? / Двор ми чува Мијай, веран слуі̄a (Кор. 151).

д) Посебну стилску варијацију представљају они искази који имају карактер труизама, пословичких аксиома (исп. Јовановић 2000: 662), а заправо су симптоми пишчеве интелектуализације поетског наратива, са 'позајмљеном' идиоматизованом формом:

Веруј ми, у злу су људи зли (Кор. 11); Срамота се не брише срамотом (Кор. 21); Кад се јасену врх осуши, он из пања истера шибљик (Кор. 33); Бриге су ти као вода: дођу и прођу. Човек ти је као река. Кроз њега мора све да протекне (Кор. 170); Сви су људи реке са много вода измешане и шарени као ливаде (Кор. 212); Човек није травка па да може и од најљућег косача последње коленце да скрије и опет под сунцем да издужи врат (Кор. 214); Само људи умиру на вешалима. Ниједан други живи створ (Кор. 243).

2. За следећа два Ћосићева текста која препоручујемо за основношколску обраду - предлажемо и у односу на пређашња друкчија методолошка решења и друкчије методичке обрасце. Први од та два може изазвати отпор због природе дела из којег је преузет. А узимамо га из 
Бајке (Ћосић 2016), дела тамног смисла и помало мистичне садржине. Фантастична књижевност по себи свакако је добродошла за рад са ученицима, али фантастика ипак мора бити на неки начин одгонетљива, порука једнозначна - цела прича у крајњој линији транспарентна. Бајка то свакако није. Писало се о њој да позадина свакако мора бити политичке природе, те би одгонетање метафора и симбола одвело аналитичара на поприште политичких обрачуна онога доба. Нама се, мећутим, намећу с тим у вези различита поређења, нпр. са делима која су својевремено имала статус и улогу значајних друштвено-критичких остварења, а затим - изгубивши у новим условима тај смисао - постала важна лекти$\mathrm{pa}^{8}$ за децу и омладину. Таква су чувена Гуливерова йуйовањ Свифта или сл., а код нас Домановићеве сатире.

а) Не може се сасвим избећи целокупна мрежа асоцијација у Бајu, , али текст који предлажемо за анализу у школи заправо би био прикладна база за вежбања из познавања тропике као феномена по себи, ван било којег контекста у којем је настала:

Улазимо у алеју цвећа, високог и разгранатог као липе или кестенови. Мирис зумбула ошамути ме, пао бих да ме Платон не придржава.

Какав је то зумбул који толико мирише и који је већи од липе.

Није то зумбул, мали мој незнанко. Он је рекао да улице и булевари Камоније треба увек тако јако да миришу, да женама и људима никад не затребају вештачки мириси. И зато сада у свим нашим градовима постоје булевари кезуме, булевари плавке, булевари рушхра, булевари тоњила, тргови баче, сонуса, асхе и тако даље. Сем у камонији, такво цвеће нигде на свету не расте.

А ова љубичица или врба, шта је то?

То је бача. Добијена је укрштањем обичне љубичице и обичне врбе. Бачом су засађени тргови на којима најрадије уживају девојчице и баке. Под цветовима баче, као што видиш већим од обичног сунцобрана, девојчице једу сладолед а баке пију чај. После се девојчице играју а баке, опијене модрим мирисом, сећају се младалачких успомена (Бај. 147-148).

б) Одрасли овај текст препознају као иронију пуну алузија на неког моћника ('Он') у чију част се све дешава што се дешава у чудној земљи са још чуднијим називом 'Камонија'. То је 'обећана земља', у којој је све изузетно, најбоље и најлепше, какво „нигде на свету не расте”. По 'Његовом' налогу укрштају се биљке и добијају мамутски хибриди најчуднијих особености: огромних димензија и продорног мириса. Све добија карикатуралне димензије, и за све постоје гротескни називи. Дечјој пак свести најпре су приступачни необични називи биљака. У првом читању

\footnotetext{
${ }^{8}$ Упоредили смо и следећа мишљења: Марковић 1991; Вуковић 1996; Петровић 2011.
} 
мислиће да је то свет који негде стварно постоји, па ће им се онда ипак представити као шала. У тој шали препознаће свакако најпре хиперболу, а уз мало напора уочиће иронични тон излагања. На крају ће вероватно бар најнапреднији утврдити карикатуру, па и гротескне обрисе описа.

в) Наставнику би се могла оставити слобода даљег тумачења - дакле да са ученицима уочи критички тон и сатиричну оштрицу описа ${ }^{9}$ која се тиче лажне величине онога по чијим инструкцијама бива све што се у 'Камонији' догађа. Називи за биљке делују у том контексту као празне речи хвалисаве намене срачунате на јефтин политички ефекат у корист онога по чијој се вишој вољи све дешава како је 'рекао'.

3. Трећи текст који предлажемо вероватно се и налази у неким читанкама старијег датума, а данас се више не сматра 'подобним' - Далеко је суни,е (Ћосић 2000). Но овај Ћосићев роман, сем описа борбе против окупатора и унутрашњих трагичних подела и сукоба ${ }^{10}$ за време Другог светског рата - у епопејни центар поставља човека појединца који се нашао на ветрометини као на гиљотини, нападнут са свих страна и беспомоћан - куда да крене и шта да чини у одбрани голе егзистенције: за Тита и Партију или за Краља и Отаџбину.

а) Ево једног примера у којем писац до у микрокозмичке ћелије прати егзистенцијалну борбу човека да елементарно преживи. Дечак лагано умире од умора, глади и хладноће. Снежни пропланак пред његовим већ малаксалим чулима претвара се у призор лепоте и благостања за какво једино зна и које носи са домаћег огњишта:

У Малишиним зеленкастим очима сањарила је уморна глад. Сањарила је о врућој проји испеченој у жеравици и пепелу коју мајка издувава, лупа длановима и брише кецељом. Још једном обрише модром пртеном кецељом, још једном лупи тамним, тврдим длановима са обадве стране, а онда је спусти на сто. Проја се сама разломи и зажути се. Извија се облачак беличасте паре... У плавом тањиру, као грудве снега, сир. Више шпорета, у плитким јасиковим карлицама, намрешкала се жућкаста површина кајмака. Снежни пропланак клобучао је и пенио као закувано млеко у огарављеном бакрачу.

${ }^{9}$ Пожељно би било на овом примеру показати однос између описа и коментара нпр. у Ћосићеву наративу, и уопште. За ову вежбу ваљало би наћи примере микрокоментара и макрокоментара. Овај први могу илустровати и сцијентизми које наводимо за примере у овом раду, а за други случај треба одабрати један текстовни интервал (од најмање три исказа) (исп. о томе више у: Милосављевић-Милић 2006; Јовановић Симић, Симић 2015).

10 У сижејној потки овог наратива стоје дани тешког опстанка и обезглављености српског народа у процепу међу великим силама сукобљеним врло жестоко над главама српског народа, и великим идеолошким замршајима у њиховој свести које су их растрзале уместо да их обједине у пропасти која је претила заправо уништењем српства. 
Све се бели, клобуча и мрешка.

- Шта то тако гледаш, Малиша, - тихо упита Уча. Њих двојица седели су близу један другог.

- Ништа... - прошапта Малиша загледан и даље у снег.

- Како ништа?

- Гладан сам (ДСун. 280-281).

б) Овакви описи звуче нестварно у ушима млађих генерација, али нас подсећају какав је морао изгледати живот српског сељаштва одвајкада па до његовог крвавог краја у Другом светском рату и после њега. Танка нит егзистенције под сталном претњом расрбљења или рашчеречења међу непријатељским силама које су сурово владале судбином сваког појединца, а често без икакве заштите у сопственом колективу, обезглављеном и немоћном да се згусне и брани сопственом снагом. Родно огњиште отањило, сеобама охлађено, ратовима пустошено, раздорима распето, - спало на парче проје из мајчине кецеље, и у срећним тренуцима мало сира, каткад и кајмака. И то је срећа о којој сања Малиша умирући у дубоком снегу, на јутарњем мразу, од глади.

в) Да ли је овом призору потребан идеолошки додатак, политичко осветљење саткано неодговорном памећу и сплетено у причу о нама и њима? Не! Дубина трагедије Малишина већа је од досега било које идеологије, било које историјске науке која би својим исхитреним аргументима покушала да окриви ову или ону страну за смрт дечака од глади у снегу. Ми ту видимо трагичну судбину српског народа, ненаклоњену историју, погрешно усмерене рецепторе прастарих наших предака који су у сеобама бирали овај простор или били сатерани у њега злом срећом (исп. Станојевић 2008).

г) У сваком случају, пред нама је опис који ће дирнути и најокорелијег поклоника ове или оне идеологије, овог или оног научног правца у објашњењу те судбине, и опоменути га да је живот вреднији од свих идеологија. Идеологије би требало да служе појединцу, народима и човечанству, а не да их доводе пред руб катаклизме. Мисао која нам се на крају нашла у глави док скрушено молимо за живот дечака и чудо које га може спасти - јесте да се ваља чувати ратничких заноса, а вратити реалности живота и потреби опстанка овог народа, тражити пут за његово спасење. Пут очувања људских живота. 


\section{3. Закључне напомене}

1. О свему наведеном може се прочитати у Ћосићеву делу, као и о много чему другом, важнијем за опстанак појединца и народа уопште него у онима много сладуњавијим а доживљајем празним причицама којима се данас пуне дечје читанке и опримеравају теоријске измишљотине којима се ове причице оправдавају као уметност.

2. Ми смо у складу са овом идејом учинили избор из Ћосићева романескна опуса и предложили одређена теоријско-методолошка решења у интерпретацији његових романа, - и то како она која се тичу тематско-мотивског фундирања нарације тако и нека решења у односу на композиционе и језичкостилске поступке (метаплазматичост и метасемичност, у најширем смислу, те конкретније: метафоричност, антропоморфизираност, персонификованост и сл.). Верујемо да ће ученици препознавањем оваквих начина стилизације лакше разумевати пишчев избор вербализацијских поступака, карактеристичних иначе по честом смењивању наративизације описа и лиризације нарације.

\section{ИЗВОРИ И ЛИТЕРАТУРА}

Бајић, Љиљана, и Зона Мркаљ. Чийанка за 8. разреg основне школе. Београд: Завод за уџбенике, 2016. Шт.

Несторовић, Зорица, и Златко Грушановић. Чийанка за 8. paзреg основне школе „Речи муgростии”. Београд: Klett, 2016. Шт.

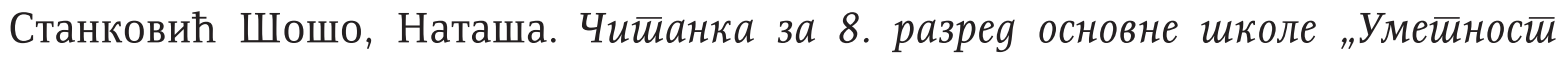
речu". Београд: Нови Логос, 2016. Шт.

Ћосић, Добрица. Корени. Београд: Просвета, 1954. Шт.

Ћосић, Добрица. Далеко је сунще. Београд: Филип Вишњић, 2000. Шт.

Ћосић, Добрица. Бајка. Београд: Лагуна, 2016. Шт.

Абот, Портер. Увоg у йеорију йрозе. Београд: Службени гласник, 2009. Шт.

Vuković, Novo. Uvod u književnost za djecu i omladinu. Podgorica: Unireks, 1996. Št.

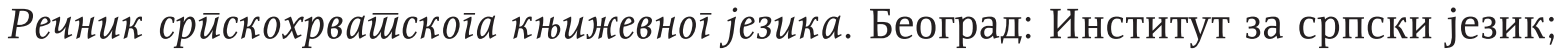
Нови Сад: Матица српска, 1967-1976. Шт.

Јовановић, Јелена. „Три аспекта анализе исказа (Исказне форме у роману 'Корени' Добрице Ћосића)". Срйски језик, V/1-2 (2000): 641-677. Шт.

Јовановић, Јелена. „О локалној и сличној лексици у Ћосићевим 'Коренима'”. Науини сасиианак славистиа у Вукове gане, 38/1 (2009): 163-176. Шт.

Јовановић Симић, Јелена, и Радоје Симић. Вербайолойија. Београд: Јасен, 2015. Шт. Јовановић Симић, Јелена. „Напомене о структури текста”. Књижевности и језик. LXIII (св. 3-4). Београд (2016): 229-242. Шт.

Јовановић Симић, Јелена. „О композицији текста са лигвистичког гледишта”. Срйски језик, XXII (2017): 75-93. Шт. 
Ковачевић, Милош. „О граматичко-стилистичком терминосистему туђег говора". Срйски језик, XVII (2012): 13-38. Шт.

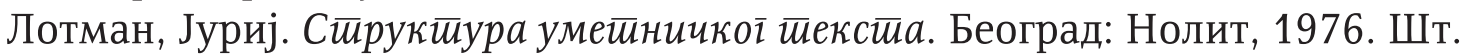

Марковић, Слободан Ж. Зайиси о књижевностии за gеиу. 5. изд. Београд: Научна књига, 1991. Шт.

Милосављевић-Милић, Снежана. Моgели коменйара у срйском роману ХІХ века. Ниш: Просвета, 2006. Шт.

Михајловић, Борислав. „Корени Добрице Ћосића” (предговор). Добрица Ћосић. Корени. Београд: Просвета, 1954. Шт.

Петровић, Тихомир. Увоg у књижевности за gеиу. Нови Сад: Змајеве дечје игре; Ниш: Свен, 2011. Шт.

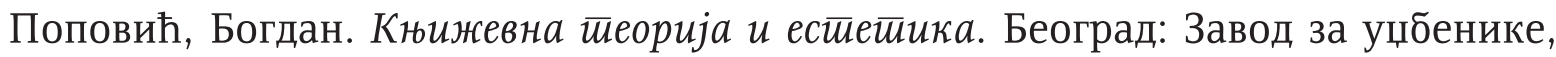
2001. Шт.

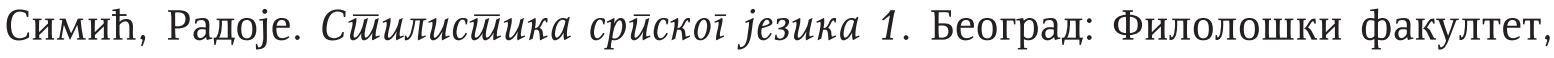
Јасен, 2000. Шт.

Симић, Радоје. „Нормативни и употребни статус футуроида ћу/ћеш... + да + презент". Науини састианак славистиа у Вукове gане, 38/1 (2009): 51-55. Шт.

Симић, Радоје, и Јелена Јовановић. „О Ћосићевим јунацима у 'Времену власти”. Анали Филолошкої факулиеией, 23 (св. I). Београд (2011): 319-334. Шт.

Симић, Радоје, и Јелена Јовановић Симић. „Улога дијалектизама и локализама у српској књижевности доба реализма". Исхоguшйа, 3. Темишвар (2017): 407-417. Шт.

Станојевић, Станоје. Исйорија срйскої нароgа. Београд: Логос Арт, 2008. Шт.

Шкловски, Виктор Борисович. „О уметности као мишљењу сликама”. Поља 12. год. 12, бр. 93 (мај 1966): 12-21. Шт.

Ivana D. Jovanović

\section{METHOD APPROACH TO THE WORK OF DOBRICA ĆOSIĆ IN PRIMARY SCHOOL}

\section{Summary}

The author starts from the program opportunities and methodical practice in the processing of the artistic texts of Dobrica Ćosić in elementary school, and from these positions, on selected examples - he tries to offer some new reviews on the thematic-motive structure of Ćosić's prose, for the sake of the word, for children - and actually suitable for language and cognitive abilities of students of elementary school age. According to this idea, the author suggests recognizing thematically diverse motifs (towards the spheres of life), highlighting the domi- 
nant ones, which are national and family values. In accordance with this selection, certain theoretical and methodological solutions in the interpretation of Ćosić's novels are also proposed, precisely those related to the composition and languagestyle process (metaplasmatic and metasemic methods: metaphorization, anthropomorphization, personification). 